\title{
HUBUNGAN KONTROL DIRI DENGAN SMARTPHONE ADDICTION PADA MAHASISWA PENGGUNA SMARTPHONE DI PROGRAM STUDI S1 TEKNIK ELEKTRO UNIVERSITAS NEGERI MALANG
}

\author{
Dessy Rifa Anzani, Sudjiwanati, Essha Paulina Kristianty \\ Universitas Wisnuwrdhana, Universitas Wisnuwrdhana, Universitas Wisnuwrdhana, \\ sitihajar.daycare@gmail.com
}

\begin{abstract}
Abstrak: Penelitian ini bertujuan untuk mengetahui hubungan antara kontrol diri dengan Smartphone Addiction pada mahasiswa pengguna Smartphone di program studi strata 1 Teknik Elektro Universitas Negeri Malang. Penelitian merupakan penelitian kuantitatif dengan populasi 297 dan responden yang diambil berjumlah 171 mahasiswa Teknik Elektro Universitas Negeri Malang yang dipilih menggunakan teknik Purposive sampling. Instrumen penelitian yaitu Smartphone Addiction scale dengan 32 pernyataan dan skala kontrol diri yang terdiri dari 30 pernyataan. Hasil penelitian menunjukkan bahwa mahasiswa Teknik Elektro Universitas Negeri Malang memiliki tingkat kontrol diri 69,01\% (118 mahasiswa) dan Smartphone Addiction 70,18\% (120 mahasiswa) dalam katagori sedang. Hasil Uji korelasi menggunakan uji korelasi Pearson memberikan hasil $r$ hitung sebesar -0,541 yang lebih besar dari $r$ tabel yaitu 0,1262. Hal ini menujukkan ada hubungan antara kontrol diri dan Smartphone Addiction. Nilai $\mathrm{r}$ hitung tersebut bernilai negatif yang berarti korelasi antara dua variabel tersebut adalah korelasi negatif yang artinya semakin tinggi kontrol diri individu, maka semakin rendah Smartphone Addiction yang dialami, begitupun sebaliknya.
\end{abstract}

Kata Kunci: Kontrol Diri, Smartphone Addiction, Mahasiswa Teknik Elektro

\begin{abstract}
This study aims to determine the relationship between self-control and Smartphone Addiction on Smartphone user students in the undergraduate study program in Electrical Engineering, State University of Malang. The research is a quantitative study with a population of 297 and respondents taken amounted to 171 students of Electrical Engineering Malang State University who were selected using Purposive sampling technique. The research instrument is the Smartphone Addiction scale with 32 statements and a self-control scale consisting of 30 statements. The results showed that Electrical Engineering students at State University of Malang had a self-control level of 69.01\% (118 students) and Smartphone Addiction 70.18\% (120 students) in the medium category. Correlation test results using Pearson correlation test gives the $r$ count of -0.541 which is greater than $r$ table that is 0.1262 . This shows there is a relationship between self control and Smartphone Addiction. The value of r count is negative, which means the correlation between the two variables is a negative correlation, which means the higher the individual's self control, the lower the Smartphone Addiction experienced, and vice versa.
\end{abstract}

Keywords: Self Control, Smartphone Addiction, Electrical Engineering Students

\section{PENDAHULUAN}

Setiap mahasiswa diharapkan untuk dapat mengkontrol diri terutama dalam tanggung jawab akademik maupun non akademik yang ditempuh dalam kegiatankegiatan sehari-hari, Seperti halnya menggunakan Smartphone. Individu mampu mengkontrol diri dalam 
menggunakan Smartphone dengan sewajarnya, namun apabila kontrol diri tersebut rendah maka akan mengganggu kegiatan yang dilakukan sehari-hari.

Rodin mengungkapkan kontrol diri adalah perasaan bahwa seseorang dapat membuat keputusan dan mengambil tindakan yang efektif untuk menghasilkan akibat yang diinginkan dan menghindari akibat yang tidak diinginkan (Sarafino, 1990). Ghufron dan Risnawita (2017) berpendapat bahwa kontrol diri dapat diartikan suatu pengendalian tingkah laku. Pengenalian tingkah laku mengandung makna, yaitu melakukan pertimbanganpertimbangan terlebih dahulu sebelum memutuskan sesuatu untuk bertindak. Semakin tinggi kontrol diri semakin intens pengendalian terhadap tingkah laku.

Ketidaknyamanan pada saat berjauhan dengan Smartphone erat dengan fenomena yang terjadi pada masyarakat zaman sekarang, namun permasalahan Smartphone dapat disangkutkan dengan kontrol diri. Kontrol diri dapat diartikan sebagai keputusan dan tindakan efektif untuk menghasilkan akibat yang diinginkan. Individu yang memiliki kontrol diri rendah dalam penggunaan Smartphone yang berlebihan hingga mengganggu aktivitas akan lebih mudah mengalami ketergantungan atau Smartphone Addiction dibandingkan dengan individu yang memiliki kontrol diri tinggi. Keadaan emosional, kognitif, dan fisik yang dimiliki oleh setiap individu berbeda-beda, maka kontrol diri setiap individu pada saat melakukan suatu aktivitas tertentu juga berbeda.

Perilaku Smartphone Addiction dapat dikatakan sebagai perilaku kecanduan apabila seseorang tidak dapat mengontrol keinginannya dan menyebabkan dampak negatif pada diri individu yang bersangkutan. Smartphone Addiction adalah perilaku keterikatan atau kecanduan terhadap Smartphone yang memungkinkan menjadi masalah sosial seperti halnya menarik diri dan kesulitan dalam performa aktivitas sehari-hari (Karuniawan \& Cahyanti, 2013).

Mahasiswa Program Studi Strata 1 Teknik Elektro adalah termasuk mahasiwa yang sudah familiar dengan Smartphone. Sebagai mahasiswa Teknik Elektro belajar tentang bidang ilmu yang berkaitan dengan teknologi terbaru, penggunaan Smartphone adalah hal yang biasa. Berbagai macam fitur dalam Smartphone bisa digunakan oleh mahasiswa program studi strata 1 Teknik Elektro. Mereka cukup cepat dalam mendapatkan informasi terkait tren terbaru terkait dengan teknologi, mulai dari spesifikasi Smartphone terbaru, media sosial terbaru, game terbaru, dan berbagai macam aplikasi terbaru.

Di selasar gedung G4 Fakultas Teknik Universitas Negeri Malang, sering ditemui mahasiswa sedang beraktifitas dengan Smartphone nya baik itu untuk keperluan chatting, browsing, menonton video ataupun bermain game. Hal yang sama juga terjadi di lorong di dalam gedung perkuliahan dan laboratorium. Aktifitas ini kadang kala berlanjut ketika mahasiswa sedang mengikuti perkuliahan ataupun praktikum sehingga mahasiswa tidak fokus memperhatikan materi perkuliahan ataupun praktikum.

Penggunaan Smartphone juga terjadi pada mahasiswa di Program Studi Strata 1 Teknik Elektro Universitas Negeri Malang. Mahasiswa tersebut umumnya memiliki Smartphone yang digunakan untuk berbagai aktifitas seperti berkomunikasi dengan teman dan dosen, mengakses jejaring sosial, mengakses konten video, bermain game dan lain-lain. Di sekitar dan di dalam gedung perkuliahan dan laboratorium disediakan fasilitas wi-fi dengan kecepatan tinggi yang bisa diakses melalui smartphone. Fasilitas wi-fi ini mendukung penggunaan Smartphone oleh mahasiswa. Fasilitas wi-fi di sekitar gedung ini lebih terawat dibandingkan dengan fakultas lain karena jurusan Teknik Elektro memiliki tenaga 
laboran yang memahami prosedur penanganan fasilitas wi-fi. Sehingga akses wi-fi di gedung ini lebih baik dibandingkan fakultas lain.

Berdasarkan latar belakang masalah di atas, maka penulis tertarik untuk melakukan penelitian dengan mengangkat topik hubungan kontrol diri dengan Smartphone Addiction pada mahasiswa pengguna Smartphone di program studi Strata 1 Teknik Elektro Universitas Negeri Malang.

\section{METODE}

Penelitian ini dilaksanakan dengan menggunakan penelitian korelasional. Adapun variabel yang digunakan dalam penelitian adalah sebagai berikut.

1. Variabel bebas: Kontrol diri

2. Variabel terikat: Smartphone Addiction

\section{Populasi}

Adapun populasi dalam penelitian ini adalah mahasiswa dan mahasiswi Fakultas Teknik Jurusan Teknik Elektro Negeri Malang berjumlah 297 orang.

\section{Sampel}

Sampling sendiri menurut Sugiyono (2014) adalah teknik pengambilan sample. Teknik samling yang digunakan dalam penelitian ini adalah Purposive sampling. Menurut Idrus (2009) teknik Purposive sampling adalah teknik sampling yang digunakan oleh peneliti jika memiliki pertimbangan-pertimbangan atau kriteria tertentu dalam pengambilan sampelnya yang berhubungan erat dengan tujuan penelitian. Adapun kriteria Sample adalah:

a) Mahasiswa atau mahasiswi Strata 1 Teknik Elektro Universitas Negeri Malang

b) Memiliki Smartphone

c) Aktif menggunakan Smartphone.

Jumlah populasi yakni seluruh mahasiswa Strata 1 Teknik elektro Universitas Negeri Malang sebanyak 297 mahasiswa dan peneliti mengambil sampel dengan menggunakan teknik Slovin (Sugiyono, 2014). Rumus Slovin untuk menentukan sampel adalah sebagai berikut.

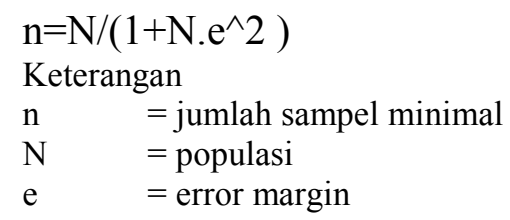

Error margin yang diharapkan dari penelitian ini adalah 5\%. jumlah populasi dalam penelitan ini adah 297 sehingga jumlah sampel penelitian adalah 171 orang

\section{Smartphone Addiction}

Smartphone Addictions adalah perilaku keterikatan atau kecanduan terhadap Smartphone memungkinkan menjadi masalah sosial maupun pribadi seperti halnya, gangguan kehidupan seharihari, antisipasi positif, penarikan, hubungan berorientasi dunia maya, penggunaan berlebihan, dan toleransi.

Perilaku dapat dikatakan sebagai perilaku kecanduan apabila seseorang tidak dapat mengontrol keinginannya. Cara mengetahui tingkat Smartphone Addiction pada mahasiswa skala Likert yaitu Smartphone Addiction Scale (SAS) yang diadaptasi dari Kwon, dkk. (2013) diperoleh 6 aspek yaitu daily-life disturbance, positive anticipation, withdrawal, cyberspaceoriented relationship, overuse dan tolerance.

Smartphone Addiction Scale dikembangkan dari K-Scale yaitu sebuah skala yang tersusun dari 40 butir yang dikembangkan untuk mengukur kecanduan internet. kata-kata internet pada K-Scale kemudian diganti dengan Smartphone. Dua butir dihapus dan satu butir dirubah karena tidak sesuai dengan orang dewasa. Sepuluh pernyataan kemudian ditambahkan yang mendeskripsikan fitur mobile pada Smartphone. Semua butir kemudian direvisi oleh 6 orang profesional yang bergerak dibidang Smartphone Addiction (2 orang psikiatris, 2 orang orang psikologi klinis, dan 2 orang psikolog konseling). Semua 48 
butir tersebut dibagi menjadi 7 faktor yaitu gangguan kehidupan sehari-hari, gangguan terhadap ujian kenyataan, antisipasi positif, penarikan, hubungan berorientasi dunia maya, penggunaan berlebihan, dan toleransi. Analisa faktor menunjukan bahwa faktor gangguan ujian kenyataan harus dihapus karena hanya ada 1 pernyataan di dalam faktor tersebut. Empat belas pernyataan yang lain juga gagal untuk dikategorikan kedalam faktor-faktor tersebut, sehingga dihapuskan dari daftar pernyataan. Uji Cronbach Alpha untuk semua butir adalah 0.967 (Kwon, dkk, 2013).

Alat ukur Smartphone Addiction Scale akan diterjemahkan kedalam bahasa indonesia dan akan diuji kembali Reliabilitas dan validitas kembali oleh peneliti.

Pada Smartphone Addiction Scale Setiap butir pada skala Smartphone Addiction akan terdapat enam alternatif jawaban yaitu Sangat setuju (SS), Setuju (S), Agak Setuju (AS), Agak Tidak Setuju (ATS), Tidak Setuju (TS), Sangat Tidak Setuju (STS). Penyusunan skala dikelompokkan dalam butir Favorable. Adapun Skoring penilaian Smartphone Addiction Scale dapat dilihat pada tabel berikut.

Tabel 1. Skoring Penilaian Skala

\begin{tabular}{cl}
\hline Favourable & Jawaban \\
\hline 6 & Sangat Setuju (SS) \\
5 & Setuju (S) \\
4 & Agak Setuju (AS) \\
3 & Agak Tidak Setuju (ATS) \\
2 & Tidak Setuju (TS) \\
1 & Sangat Tidak Setuju (STS) \\
\hline
\end{tabular}

Skala Smartphone Addiction yang digunakan dalam penelitian ini berisi 33 butir dan seluruh butir merupakan butir favorable. Model skala yang digunakan adalah skala Likert. Alat ukur akan diterjemahkan kedalam bahasa indonesia dan akan diuji kembali realible dan validitasnya. Blueprint Smartphone
Addiction Scale pada penelitian ini ditunjukan pada tabel berikut.

Tabel 2. Blueprint Smartphone Addiction Scale

\begin{tabular}{llll}
\hline No & $\begin{array}{l}\text { Dimensi } \\
\text { Smartphone } \\
\text { Addiction }\end{array}$ & $\begin{array}{l}\text { Jumlah } \\
\text { Pernyataan } \\
\text { Favorable }\end{array}$ & $\begin{array}{l}\text { No } \\
\text { Item }\end{array}$ \\
\hline \multirow{2}{*}{1} & Dayly life & 5 & $1,33,2,2$ \\
& disturbance & 5,31 \\
& & & $3,4,5$, \\
2 & Positive & 8 & 29,30, \\
& anticipation & & 11,12, \\
& & & 28 \\
3 & Withdrawal & 5 & 13,27, \\
& & & 32,15, \\
& Cyberspace & & 6,7, \\
4 & oriented & 7 & $8,9,10,1$ \\
& relationship & & 6,25 \\
& & & 17,24, \\
5 & Overuse & 5 & 19,23, \\
& & & 20,21, \\
6 & Tolerance & 3 & 22 \\
& Total & & \\
& Pernyataan & 33 &
\end{tabular}

Validitas pada skala yang disusun yang teridentidikasi dengan baik, telah dibatasi dengan jelas, dan dapat dievaluasimelalui nalar dan akal sehat dapat diungkap secara layak untuk mengukur atribut yang akan digunakan oleh peneliti (Azwar, 2014). Menurut Sugiyono (2014) valid berarti instrument yang telah dibuat dapat digunakan untuk mengukur apa yang seharusnya diukur.

Pengujian menggunakan uji dua sisi dengan taraf signifikansi 0,05 . Kriteria pengujian adalah sebagai berikut.

a) Jika $r$ hitung $>r$ tabel (uji 2 sisi dengan sig. 0,05) maka instrumen atau itemitem pertanyaan berkorelasi signifikan terhadap skor total (dinyatakan valid).

b) Jika $r$ hitung $<r$ tabel (uji 2 sisi dengan sig. 0,05) atau $r$ hitung negatif, maka instrumen atau item-item pertanyaan tidak berkorelasi signifikan terhadap skor total (dinyatakan tidak valid). 
Validitas ini akan diukur menggunakan Product Moment dari Pearson. Pada uji validitas ini, rhitung yang diperoleh dari SPSS akan dibandingkan dengan rtabel. Jika rhitung>rtabel, maka butir soal skala tersebut dinyatakan valid. Nilai rtabel untuk sampel sebanyak 88 orang Hasil uji validitas instrumen Smartphone Addiction Scale dapat diketahui bahwa dari 33 butir pernyataan yang di uji coba terdapat 1 butir yang gugur (item nomer 1) dan 32 butir dinyatakan valid. Dimana butir pernyataan yang valid memiliki indeks pearson corelation pada sample sebanyak 88 orang pad Sig.0,05 (Two Tail) adalah 0,2096 .

Azwar (2009) menyebutkan bawa reliabilitas adalah sejauh mana suatu hasil pengukuran tes dapat dipercaya. Azwar (2009) menjelaskan bahwa hasil ukur yang dapat dipercaya atau Reliable adalah jika setelah melakukan pengukuran, kemudian dilakukan pengukuran kembali terhadap subjek yang sama dan waktu yang tidak terlalu jauh maka diperoleh hasil yang relatif sama. Tinggi dan rendahnya reliabilitas dapat dilihat berdasarkan nilai koefisien Cronbach's Alpha yang berada antara 0,00 hingga 1,0 (Azwar, 2009). Pengolahan data peneliti menggunakan perangkat lunak SPSS 20.0. Uji reliabilitas dapat dilakukan secara bersama-sama terhadap seluruh butir pertanyaan dalam skala (kuesioner) penelitian (Sujarweni, 2014). Adapun dasar pengambilan keputusan dalam uji reliabilitas adalah sebagai berikut.

a) Jika nilai Cronbach's Alpha $>0,60$ maka kuesioner atau skala dinyatakan reliabel atau konsisten.

b) Sementara, jika nilai Cronbach's Alpha $<0,60$ maka kuesioner atau skala dinyatakan tidak reliabel atau tidak konsisten.

Hasil uji Reliabilitas Smartphone Addiction Scale ditunjukan pada tabel berikut.
Tabel 3. Hasil Uji Reliabilitas butir Smartphone Addiction Scale

\begin{tabular}{ccc}
\hline Cronbach's Alpha & \multicolumn{2}{c}{ N of Items } \\
\hline .919 & 32 \\
\hline
\end{tabular}

Hasil uji Reliabilitas Smartphone Addiction Scale dapat diketahui bahwa Reliabilitas di atas 0,919 (Jika nilai Cronbach's Alpha $>0,60$ maka kuesioner atau angket dinyatakan reliabel atau konsisten ). Hasil 0,919 > 0,6 maka dapat disimpulkan bahwa antara variabel Smartphone Addiction memiliki tingkat Reliabilitas yang cukup tinggi.

\section{Kontrol Diri}

Definisi operasional kontrol diri menurut peneliti adalah kemampuan individu mengontrol pemikiran (kognitif), perilaku (behavior) dan mengambil keputusan secara tepat sehingga dapat menekan perilaku impulsif.

Adapun aspek kontrol diri menurut Averill yaitu kemampuan mengontrol perilaku (behavioral control), kontrol kognitif (cognitive control), dan kemampuan mengontrol keputusan (decisional control). (Ghufron dan Risnawita, 2014).

Skor kontrol diri diperoleh dari skala kontrol diri yang harus dijawab dan diisi oleh subjek. Skala kontrol diri ini berdasarkan tiga aspek yang diungkapkan Averill (Lauren Leoti, 2015) yaitu kemampuan mengontrol perilaku, kontrol kognitif, dan kemampuan mengontrol keputusan.

Pada uji validitas ini, rhitung yang diperoleh dari software akan dibandingkan dengan rtabel. Jika rhitung $>$ rtabel, maka butir soal skala tersebut dinyatakan valid. Nilai rtabel untuk sampel sebanyak 88 orang pada Sig.0,05 (Two Tail) adalah 0,2096. Hasil uji validitas instrumen Skala Kontrol Diri dapat diketahui bahwa dari 36 butir pernyataan yang di uji coba. Pada putaran pertama terdapat 7 butir yang gugur 
$(3,8,16,19,20,21,27)$ dan pada putaran kedua terdapat 1 butir yang gugur (35) dan pada putaran ketiga dinyatakan terdapat 28 butir yang valid. Blueprint skala Kontrol Diri setelah di uji coba ditunjukan pada tabel berikut.

Tabel 4. Blueprint Skala Kontrol Diri setelah di uji coba

\begin{tabular}{|c|c|c|c|c|c|}
\hline No & Aspel Kontrol Diri & Indikator & Farorable & Unfarorable & Jumlah Penyataan \\
\hline \multirow[t]{2}{*}{1} & $\begin{array}{l}\text { Kemampuan } \\
\text { mengontrol perilaku }\end{array}$ & $\begin{array}{l}\text { 1) Kemampuan } \\
\text { mengendalikan keadaan }\end{array}$ & $1,13,25$ & $2,14,26$ & 6 \\
\hline & & $\begin{array}{l}\text { 2) Kemampuan } \\
\text { mengatur stimulus }\end{array}$ & 15 & 4,28 & 3 \\
\hline \multirow[t]{2}{*}{2} & Kontrol kognitif & $\begin{array}{l}\text { 3) Kemampuan } \\
\text { mempertimbangkan } \\
\text { keadaan }\end{array}$ & $5,17,29,36$ & 12,18 & 6 \\
\hline & & $\begin{array}{l}\text { 4) Kemampuan } \\
\text { menilai keadann }\end{array}$ & 7,31 & 32 & 3 \\
\hline \multirow[t]{2}{*}{3} & $\begin{array}{l}\text { Kemampuan } \\
\text { mengontrol keputusan }\end{array}$ & $\begin{array}{l}\text { 5) Kemampuan } \\
\text { mengambil keputusasm }\end{array}$ & 9,33 & $10,22,34$ & 5 \\
\hline & & $\begin{array}{l}\text { 6) Kemampuan } \\
\text { memilih tindakan }\end{array}$ & 11,23 & $6,24,30$ & 5 \\
\hline & Total Pemyataan & & 14 & 14 & 28 \\
\hline
\end{tabular}

Hasil uji Reliabilitas Skala Kontrol Diri dapat diketahui bahwa Reliabilitas di atas 0,809 (Jika nilai Cronbach's Alpha > 0,60 maka kuesioner atau angket dinyatakan reliabel atau konsisten). Hasil uji Reliabilitas 0,809 > 0,6 maka dapat disimpulkan bahwa variabel Kontrol Diri memiliki tingkat Reliabilitas yang cukup tinggi.

Tabel 5. Uji Reliabilitas butir Kontrol Diri Reliability Statistics

\begin{tabular}{cc}
\hline Cronbach's Alpha & N of Items \\
\hline .809 & 28 \\
\hline
\end{tabular}

\section{Metode Analisis Data}

1. Uji Normalitas

Menurut Ghozali (2006), uji normalitas sebagai uji prasyarat analisis diperlukan untuk mengetahui data yang akan diolah berdistribusi normal atau tidak. Sehingga langkah selanjutnya akan menggunakan analisis statistik parametrik atau nonparametrik bisa jelas diputuskan.
Uji normalitas yang digunakan mengacu pada model uji KolmogorovSmirnov dengan bantuan komputasi IBM SPSS Statistics 20 for Windows. Normal atau tidaknya sebaran data penelitian dapat dilihat dari nilai signifikansi yang diperoleh. Kaedahnya jika nilai signifikansi yang diperoleh lebih besar dari 0.05 ( $p>0.05)$ maka data berdistribusi normal dan memakai analisis parametrik. Jika nilai signifikansi yang diperoleh lebih kecil dari $0.05(\mathrm{p}<0.05)$, maka data berdistribusi tidak normal dan memakai analisis nonparametrik.

\section{Uji Deskriptif}

Statistik deskriptif adalah statistik yang berfungsi untuk mendiskripsikan atau memberikan gambaran terhadap objek yang diteliti melalui data sampel atau populasi sebagaimana adanya, tanpa melakukan analisis dan membuat kesimpulan yang berlaku untuk umum (Sugiyono, 20078). Data variabel penelitian perlu dikategorikan dengan langkahlangkah menurut Suharsimi Arikunto(2001: 299) sebagai berikut:

a) Kelompok tinggi, semua responden yang mempunyi skor sebanyak skor rata-rata plus $1(+1)$ standar deviasi $(\mathrm{X} \geq \mathrm{Mi}+1$ SDi)

b) Kelompok sedang, semua responden yang mempunyai skor antara skor ratarata minus 1 standar deviasi dan skor rata-rata plus 1 standar deviasi (antara $(\mathrm{Mi}-1 \mathrm{SDi}) \leq \mathrm{X}<(\mathrm{Mi}+\mathrm{SDi})$

c) Kelompok kurang, semua responden yang mempunyai skor lebih rendah dari skor rata-rata minus 1 standar deviasi (X $<$ Mi- 1 SDi)

\section{Uji Linieritas}

Menurut Priyatno (2010) Uji linieritas bertujuan untuk mengetahui hubungan yang linier atau tidak secara signifikan variabel penelitian. Uji ini digunakan sebagai persyaratan dalam analisis korelasi atau regresi linier. Pengujian Linieritas pada penelitian ini menggunakan Test for 
linearity pada taraf signifikan 0,05 . Variabel penelitian dikatakan mempunyai hubungan yang linier apabila signifikansi (linieritas) kurang dari 0,05 .

Menurut Winarsunu (2010) Uji Linearitas adalah suatu prosedur yang digunakan untuk mengetahui status linier tidaknya suatu distribuusi data penelitian. Hasil yang diperoleh melalui uji linieritas akan menetukan teknik analisis yang akan digunakan. Apabila dari hasil uji linieritas didapatkan kesimpulan bahwa distribusi data linier, maka penelitian diselesaikan dengan teknik analisis linier, namun apabila distribusi data tidak linier, maka penelitian diselesaikan dengan teknik non-linier. Adapun kriteria dari uji linieritas adalah apabila $\mathrm{F}$ hitung $<\mathrm{F}$ tabel maka data tersebut adalah linier dan sebaliknya apabila diketahui harga $\mathrm{F}$ hitung $>\mathrm{F}$ tabel maka data tersebut tidak linier. Perhitungan dilakukan menggunakan program perhitungan SPSS.

\section{Uji Hipotesis}

Menurut Sugiyono (2013) hipotesis adalah jawaban sementara terhadap rumusan masalah penelitian, dimana rumusan masalah penelitian telah dinyatakan dalam bentuk kalimat pertanyaan. Dalam menguji hipotesis menggunakan uji korelasi antara dua variabel yaitu variabel bebas (variabel $X$ ), dan variabel tergantung (variabel $Y$ ) (Djarwanto \& Subagyo, 1998).

Korelasi adalah istilah statistik yang menyatakan derajat hubungan linier (searah bukan timbal balik) antara dua variabel atau lebih. Salah satu metode dalam uji korelasi adalah Product Moment Pearson. Kegunaan Korelasi Product Moment Pearson adalah untuk menyatakan ada atau tidaknya hubungan antara variabel $\mathrm{X}$ dengan variabel Y (Usman, 2000).

Teknik analisis data yang akan digunakan dalam penelitian ini adalah dengan menggunakan metode Pearson Product Moment dikarenakan melakukan uji korelasi antara dua variabel yaitu kontrol diri (X) sebagai variabel bebas, dan Smartphone Addiction pada mahasiswa (Y) sebagai variabel tergantung (Djarwanto \& Subagyo, 1998)

\section{HASIL}

\section{Uji Normalitas}

Tujuan diadakan uji normalitas adalah untuk mengetahui data yang dimiliki masing-masing variabel penelitian berdistribusi normal atau tidak. Hasil penghitungan SPSS for windows versi 20 untuk uji normalitas adalah sebagai berikut.

Tabel 6. Uji Normalitas Skala Smartphone Addiction dan Skala Kontrol Diri One-Sample Kolmogorov-Smirnov Test

\begin{tabular}{|c|c|c|c|}
\hline & & $\begin{array}{c}\text { Smartphone } \\
\text { Addiction } \\
\text { Scale }\end{array}$ & $\begin{array}{c}\text { Kontrol } \\
\text { Diri }\end{array}$ \\
\hline $\mathrm{N}$ & & 171 & 171 \\
\hline \multirow[b]{2}{*}{$\begin{array}{l}\text { Normal } \\
\text { Parameters }{ }^{\mathrm{a}, \mathrm{b}}\end{array}$} & Mean & 114.82 & 82.39 \\
\hline & $\begin{array}{l}\text { Std. } \\
\text { Deviation }\end{array}$ & 22.988 & 7.202 \\
\hline \multirow{3}{*}{$\begin{array}{l}\text { Most Extreme } \\
\text { Differences }\end{array}$} & Absolute & .060 & .089 \\
\hline & Positive & .034 & .089 \\
\hline & Negative & -.060 & -.043 \\
\hline \multicolumn{2}{|c|}{ Kolmogorov-Smirnov Z } & .785 & 1.159 \\
\hline \multicolumn{2}{|c|}{ Asymp. Sig. (2-tailed) } & .569 & .136 \\
\hline
\end{tabular}

a. Test distribution is Normal.

b. Calculated from data.

Berdasarkan uji normalitas di atas dapat diketahui:

1) Uji normalitas menggunakan metode Kolmogorov-Smirnov pada variabel skala Smartphopne Addiction menghasilkan Most Extreme Differences Absolute $=0,060$. Nilai ini kemudian dibandingkan dengan tabel KolmogorovSmirnov (KS) dengan signifikansi 0,05 untuk $\mathrm{N}=171$ sebesar 0,103857. Hasil yang didapat adalah Most Extreme Differences Absolute $(0,060)<\mathrm{KS}$ Tabel 
$(0,103857)$. Dari hasil tersebut maka distribusi skor Smartphopne Addiction dinyatakan normal.

2) Uji normalitas menggunakan metode Kolmogorov-Smirnov pada variabel skala Kontrol Diri menghasilkan Most Extreme Differences Absolute = 0,089. Nilai ini kemudian dibandingkan dengan tabel Kolmogorov-Smirnov (KS) dengan signifikansi 0,05 untuk $\mathrm{N}=171$ sebesar 0,103857 . Hasil yang didapat adalah Most Extreme Differences Absolute $(0.089)<$ KS Tabel $(0,103857)$. Dari hasil tersebut maka distribusi skor Kontrol Diri dinyatakan normal.

\section{Uji Deskriptif}

a. Kontrol Diri

Hasil deskripsi pada variabel Kontrol Diri pada mahasiswa Program Studi S1 Teknik Elektro Universitas Negeri Malang diklasifikasi menjadi beberapa kelas interval dan akan didapat beberapa kategori Kontrol Diri yakni; tinggi, sedang, dan rendah. Kategori Kontrol Diri dapat dilihat pada tabel berikut.

Tabel 7. Deskripsi Kategori Kontrol Diri

\begin{tabular}{llrr}
\multicolumn{4}{c}{ Mahasiswa } \\
\hline Tinggi & $\mathrm{X}>72,96$ & 25 & $14,62 \%$ \\
Sedang & $60,32<\mathrm{X}<$ & & $69,01 \%$ \\
& 72,96 & 118 & \\
\multirow{3}{*}{ Rendah } & $\mathrm{X}<60,32$ & 28 & $16,37 \%$ \\
& Total & 171 & $100,00 \%$ \\
\hline
\end{tabular}

Tabel Deskripsi Kategori Kontrol Diri Mahasiswa menunjukkan bahwa frekuensi terbanyak terdapat pada kategori sedang dalam interval 60,32 - 72,96 dengan jumlah mahasiswa sebanyak 118 mahasiswa, untuk itu mahasiswa Program Studi S1 Teknik Elektro Universitas Negeri Malang memiliki Kontrol Diri pada kategori sedang dengan persentase $69,01 \%$. Sedangkan pada katagori tinggi dalam interval $>72,96$ sejumlah 25 mahasiswa dengan prosentase $14,62 \%$ dan katagori rendah dalam interval $<72,96$ sejumlah 28 mahasiswa dengan prosentase $16,37 \%$.

\section{b. Smartphone Addiction}

Hasil deskripsi pada variabel Smartphone Addiction pada mahasiswa Program Studi S1 Teknik Elektro Universitas Negeri Malang diklasifikasi menjadi beberapa kelas interval dan akan didapat beberapa kategori Smartphone Addiction yakni; tinggi, sedang, dan rendah. Kategori Kontrol Diri disajikan pada tabel berikut.

Tabel 8. Deskripsi Kategori Smartphone Addiction Mahasiswa

\begin{tabular}{llrr}
\hline & & Freq & Percent \\
\hline Tinggi & $\mathrm{Y}>133,97$ & 19 & $11,11 \%$ \\
Sedang & $88,97<\mathrm{Y}<$ & & $70,18 \%$ \\
& 133,97 & 120 & \\
Rendah & $\mathrm{Y}<88,97$ & 32 & $18,71 \%$ \\
Total & & 171 & $100,00 \%$ \\
\hline
\end{tabular}

Tabel di atas menunjukkan bahwa frekuensi terbanyak terdapat pada kategori sedang dalam interval 88,97 - 133,97 dengan jumlah mahasiswa sebanyak 120 mahasiswa, untuk itu mahasiswa Program Studi S1 Teknik Elektro Universitas Negeri Malang memiliki tingkat Smartphone Addiction pada kategori sedang dengan persentase $70,18 \%$. Sedangkan pada katagori tinggi dalam interval $>133,97$ sejumlah 19 mahasiswa dengan prosentase $11,11 \%$ dan katagori rendah dalam interval $<88,97$ sejumlah 32 mahasiswa dengan prosentase $18,71 \%$.

\section{Uji Linearitas}

Uji linearitas untuk mengetahui hubungan masing-masing variabel bebas dan variabel terikat bersifat linear. Hasil penghitungan SPSS for windows 20 untuk uji linearitas terdapat pada tabel berikut. 
Tabel 9 Uji Linieritas Smartphone Addiction dan Kontrol Diri

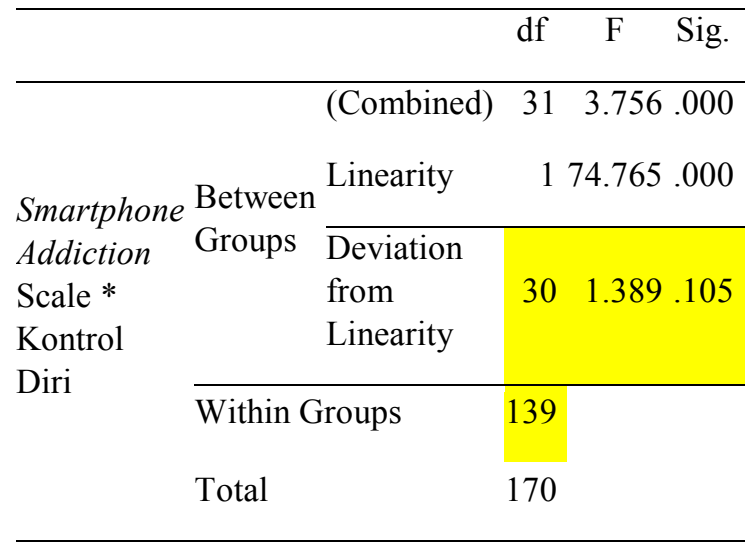

Uji Linieritas Smartphone Addiction dan Kontrol Diri dilakukan dengan membandingkan antara nilai $\mathrm{F}$ hitung dan $\mathrm{F}$ tabel. Uji Linieritas Smartphone Addiction dan Kontrol Diri menunjukkan bahwa nilai $F$ hitung adalah 1.389. Nilai $F$ tabel dicari berdasarkan nilai kolom sebesar nilai df Between Groups dan nilai baris sebesar nilai df Within Groups. Nilai F tabel yang terdapat pada kolom 30 dan baris 139 menunjukan angka 1.46. Nilai $\mathrm{F}$ tabel yang lebih besar dari pada nilai $F$ hitung menunjukkan hubungan linier antara dua variabel. Uji linearitas menunjukkan bahwa F tabel (1.46) $>$ F hitung (1.389), maka dapat disimpulkan bahwa antara variabel bebas ( $\mathrm{X}=$ Kontrol Diri) dengan variabel terikat $(\mathrm{Y}=$ Smartrphone Addiction $)$ terdapat hubungan yang linear. Berdasarkan uji linearitas yang dilakukan dapat disimpulkan bahwa asumsi linear dalam penelitian ini terpenuhi.

\section{Uji Hipotesis}

Menurut Sugiyono (2014) hipotesis adalah jawaban sementara terhadap rumusan masalah penelitian, dimana rumusan masalah penelitian telah dinyatakan dalam bentuk kalimat pertanyaan. Dalam menguji hipotesis menggunakan teknik Pearson Product Moment dikarenakan melakukan uji korelasi antara dua variabel yaitu Kontrol
Diri (X) sebagai variabel bebas, dan Smartphone Addiction pada mahasiswa (Y) sebagai variabel tergantung (Djarwanto \& Subagyo, 1998). Berdasarkan hasil pengumpulan data di Jurusan Teknik Elektro Universitas Negeri Malang dapat diketahui dengan penghitungan SPSS for windows 20 , sebagai berikut.

Tabel 10. Uji Hipotesis

\begin{tabular}{|c|c|c|c|}
\hline & & $\begin{array}{l}\text { Smartphone } \\
\text { Addiction } \\
\text { Scale }\end{array}$ & $\begin{array}{l}\text { Kontrol } \\
\text { Diri }\end{array}$ \\
\hline \multirow{4}{*}{$\begin{array}{l}\text { Smartphone } \\
\text { Addiction } \\
\text { Scale }\end{array}$} & $\begin{array}{l}\text { Pearson } \\
\text { Correlation }\end{array}$ & 1 & $-.541^{* *}$ \\
\hline & Sig. (2-tailed) & & .000 \\
\hline & $\mathrm{N}$ & 171 & 171 \\
\hline & $\begin{array}{l}\text { Pearson } \\
\text { Correlation }\end{array}$ & $-.541^{* *}$ & 1 \\
\hline \multirow{2}{*}{ Kontrol Diri } & Sig. (2-tailed) & .000 & \\
\hline & $\mathrm{N}$ & 171 & 171 \\
\hline
\end{tabular}

**. Correlation is significant at the 0.01 level (2tailed).

Uji korelasi antara variabel Kontrol Diri (X) dengan Smartphone Addiction pada mahasiswa (Y) dilakukan dengan menggunakan teknik Pearson Product Moment. Pada uji korelasi Pearson, dua buah variabel dikatakan memiliki korelasi jika nilai $r$ hitung lebih besar dari $r$ tabel pada nilai $\mathrm{N}$ sejumlah subyek penelitian. Untuk nilai $\mathrm{N}$ sebesar 171, nilai $\mathrm{r}$ tabel adalah 0,1262. Nilai $r$ hitung pada uji korelasi ini adalah 0,541 . Nilai $r$ hitung $(0,541)$ lebih besar dari $r$ tabel $(0,1262)$ sehingga dapat dikatakan bahwa terdapat korelasi antara variabel Kontrol Diri (X) dengan Smartphone Addiction pada mahasiswa (Y).

Nilai $r$ hitung yang bernilai negatif menujukkan bahwa korelasi antara dua variabel tersebut adalah korelasi negatif. Korelasi negatif atau hubungan negatif yang signifikan antara kontrol diri dan Smartphone Addiction pada mahasiswa. Artinya, semakin tinggi kontrol diri individu, maka semakin rendah Smartphone Addiction yang dialami, begitupun sebaliknya, semakin rendah kontrol diri 
individu, maka Smartphone Addiction yang dialami akan semakin tinggi.

\section{PEMBAHASAN}

Penelitian ini dilakukan untuk mengetahui bagaimana hubungan antara Kontrol Diri dan Smartphone Addiction pada Mahasiswa Teknik Elektro Strata 1 di Universita Negeri Malang. Penelitian ini memiliki hipotesis yang menyatakan ada hubungan antara Kontrol Diri dengan Smartphone Addiction. Hal tersebut dapat diartikan bahwa Kontrol Diri memiliki kaitan dengan Smartphone Addiction atau ketergantungan dalam penggunaan telphon pintar.

Bedasarkan dari hasil penelitian yang sudah dilakukan peneliti pada variable tingkat Kontrol diri (X) pada katagori tinggi berjumlah 25 mahasiswa dengan prosentase $14,62 \%$, sedangkan pada katagori sedang berjumlah 118 mahasiswa, dengan prosentase $69,01 \%$ dan pada katagori rendah berjumlah 28 mahasiswa, dengan prosentase $16,37 \%$ Dari total responden sebanyak 171 mahasiswa.

Hasil analisis menunjukan bahwa sebagian besar mahasiswa Teknik Elektro Universitas Negeri Malang memiliki tingkat kontrol diri yang sedang, dengan prosentase 69,01\% sebanyak 118 mahasiswa. Hal ini mengindikasi bahwa mahasiswa Teknik Elektro Universitas Negeri Malang cukup mampu mengatur untuk menahan diri atau mengarahkan diri ke arah yang lebih baik ketika dihadapkan dengan godaan-godaan (Baumeister dkk, 2012).

Pada katagori tinggi berjumlah 25 mahasiswa dengan prosentase 14,62\%. Mahasiswa dengan dengan kontrol diri yang tinggi akan mampu mengontrol kognitifnya sehingga dapat mengontrol keputusan yang diambil, dan bagaimana dirinya berperilaku. Hal ini mengidentifikasi bahwa mahasiswa mampu mengkontrol diri, baik dari mengontrol kognisinya, mengotrol perilakunya maupun mengontrol bagaimana mahasiswa tersebut mengambil keputusan
(Averill dalam Ghufron dan Risnawita, 2014).

Pada kategori rendah berjumlah 28 mahasiswa dengan prosentase $16,37 \%$. Hal ini mengindifikasi bahwa mereka kurang mampu mengontrol diri. Gottfredson dan Hirschi menyatakan bahwa individu yang memiliki kontrol diri yang rendah memiliki ciri-ciri berikut: cenderung bertindak secara impulsif, menghindari tugas yang rumit, egois, menghadapi masalah dengan tindakan fisik, sulit mengontrol emosi yang menyebabkan mudah frustasi, cenderung mudah terlibat dalam tindakan kriminal dan perilaku yang menyimpang (Phytian, 2008).

Hasil analisis Smartphone Addiction menunjukan bahwa sebagian besar mahasiswa Teknik Elektro Universitas Negeri Malang dalam kategori sedang, dengan nilai prosentase 70,18\% (120 Mahasiswa). Kategori rendah berjumlah 32 Mahasiswa dengan prosentase $18,71 \%$. Dari jumlah mahasiswa tersebut menunjuklan bahwa tidak ada keterikatan pada Smartphone. Pada kategori tinggi berjumlah 19 mahasiswa dengan prosentase $11,11 \%$. Hal ini berdampak pada perilaku keterikatan atau kecanduan terhadap Smartphone memungkinkan menjadi masalah sosial seperti halnya menarik diri dan kesulitan dalam performa aktivitas sehari-hari atau sebagai gangguan kontrol impuls terhadap diri seseorang, (Kwon, dkk, 2013).

Hasil analisis diskriptif yang sudah didapat, mahasiswa Teknik Elektro Universitas Negeri Malang memiliki tingkat kontrol diri $69,01 \%$ dan Smartphone Addiction $70,18 \%$ juga dalam katagori sedang. Dari hasil penelitian dapat disimpulkan bahwa terdapat hubungan antara kontrol diri dengan Smartphone Addiction.

Berdasarkan uji hipotesis yang telah dilakukan, Uji korelasi antara variabel Kontrol Diri (X) dengan Smartphone Addiction pada mahasiswa (Y) dilakukan dengan menggunakan teknik Pearson 
Product Moment. Pada uji korelasi Pearson, dua buah variabel dikatakan memiliki korelasi jika nilai $r$ hitung lebih besar dari $r$ tabel pada nilai $\mathrm{N}$ sejumlah subyek penelitian. Untuk nilai N sebesar 171, nilai $r$ tabel adalah 0,1262 . Nilai $r$ hitung pada uji korelasi ini adalah 0,541 . Nilai $r$ hitung $(0$, 541) lebih besar dari $r$ tabel $(0,1262)$ sehingga dapat dikatakan bahwaa terdapat korelasi antara variabel Kontrol Diri (X) dengan Smartphone Addiction pada mahasiswa (Y). Nilai $r$ hitung yang bernilai negatif menujukkan bahwa korelasi antara dua variabel tersebut adalah korelasi negatif.

Korelasi negatif atau hubungan negatif yang signifikan antara kontrol diri dan Smartphone Addiction pada mahasiswa. Artinya, semakin tinggi kontrol diri individu, maka semakin rendah Smartphone Addiction yang dialami, begitupun sebaliknya, semakin rendah kontrol diri individu, maka Smartphone Addiction yang dialami akan semakin tinggi. Hal ini sesuai dengan faktor-faktor yang dikemukakan Nur Ghufron dan Rini (2014) yakni pada faktor internal yang ikut andil terhadap kontrol diri adalah usia. Semakin bertambah usia seseorang, maka semakin baik kemampuan mengontrol diri seseorang itu. Mahasiswa dalam perkembangannya memasuki fase dewasa awal.

Menurut Hurlock (1994), dewasa awal adalah masa perubahan-perubahan yang nampak antara lain perubahan dalam hal penampilan, fungsi-fungsi tubuh, minat, sikap, serta tingkah laku sosial. Hal ini sesuai dengan yang dikemukakan oleh Monks (2006) bahwa pada usia dewasa seseorang sudah dianggap dewasa dan selanjutnya dianggap sudah mempunyai tanggung jawab terhadap perbuatanperbuatannya. Dari beberapa pendapat tersebut maka terdapat hubungan dengan hasil penelitian bahwasannya salah satu faktor kontrol diri dipengaruhi oleh usia, Dan responden yang dipilih oleh peneliti adalah mahasiswa yang memiliki rentang usia 18-23 Tahun dimana pada usia tersebut memasuki fase dewasa dini.

\section{KESIMPULAN}

Berdasarkan hasil penelitian dapat disimpulkan bahwa hipotesis diterima, dengan kata lain dalam penelitian ini ada hubungan antara kontrol diri dengan Smartphone Addiction pada mahasiswa Fakultas Teknik Elektro Universitas Negeri Malang.

Hubungan antara kontrol diri dengan Smartphone Addiction menujukkan adanya korelasi negatif atau hubungan negatif. Korelasi negatif atau hubungan negatif yang signifikan antara kontrol diri dan Smartphone Addiction pada mahasiswa. Artinya, semakin tinggi kontrol diri individu, maka semakin rendah Smartphone Addiction yang dialami, begitupun sebaliknya, semakin rendah kontrol diri individu, maka Smartphone Addiction yang dialami akan semakin tinggi.

Hasil analisis diskriptif yang sudah didapat, mahasiswa Teknik Elektro Universitas Negeri Malang memiliki tingkat kontrol diri 16,37\% dalam kategori rendah, $69,01 \%$ dalam kategori sedang, dan 14,62\% dalam kategori tinggi. Hasil analisis diskriptif menunjukkan bahwa mahasiswa Teknik Elektro Universitas Negeri Malang memiliki tingkat Smartphone Addiction yang terbagi menjadi $18,71 \%$ dalam kategori rendah, $70,18 \%$ dalam kategori sedang, dan $11,11 \%$ dalam kategori tinggi. Dari hasil penelitian dapat disimpulkan bahwa terdapat hubungan antara kontrol diri dengan Smartphone Addiction.

\section{SARAN}

Berdasarkan kesimpulan di atas, ada beberapa saran yang diberikan oleh peneliti dan dapat dimanfaatkan oleh :

1) Mahasiswa Fakultas Teknik Elektro Negeri Malang 
Mahasiswa disarankan untuk tidak berlebih menggunakan smartphone dengan cara memperbanyak kegiatan baik didalam kampus maupun diluar kampus misalnya mengikuti organisasiorganisasi yang berguna untuk mengurangi penggunaan smartphone, sehingga tingkat Smartphone Addiction yang terjadi pada mahasiswa Program Studi Strata 1 Teknik Elektro Universitas Negeri Malang tidak masuk pada golongan yang tinggi terhadap Smartphone Addiction.

2) Intansi Program Studi Strata 1 Teknik Elektro Universitas Negeri Malang

a. Instansi Program Studi Strata 1 Teknik Elektro Universitas Negeri Malang diharapkan mengadakan seminar/ penyuluhan/ psikoedukasi mengenai dampak Smarphone Addiction.

b. Memberikan konseling terhadap mahasiswa terutama yang sudah mengalami Smartphone Addiction.

c. Instansi memotivasi mahasiswa mengikuti kegiatan diluar pembelajaran seperti organisasi, ekstrakulikuler maupun club agar mengurangi dampak Smartphone Addiction.

3) Peneliti selanjutnya

a. Peneliti selanjutnya yang akan mengangkat topik yang sama ataupun mengembangkan penelitian yang serupa dapat melakukan penelitian yang lebih terfokus, misalnya pada smarphone berisi fasilitas-fasilitas seperti media sosial, youtube, game dan lain-lain yang dapat dihubungkan dengan kontrol diri.

b. Harapan peneliti terhadap peneliti berikutnya adalah dapat melakukan penelitian dengan melibatkan responden dari berbagai jenjang usia dan pendidikan seperti pada anak usia dini, SD, SMP, SMA, perguruan tinggi, hingga pekerja sehingga didapat gambaran yang lebih jelas mengenai peran tingkat kontrol diri individu terhadap penggunaan Smartphone.

c. Penelitian selanjutnya diharapkan dapat menggali lebih dalam mengenai berbagai dampak penggunaan Smartphone maupun aspek-aspek yang mempengaruhi tingkat kontrol diri.

\section{DAFTAR PUSTAKA}

Arikunto, Suharsimi. (2001). Prosedur Penelitian: Suatu Pendekatan Praktek. Jakarta: Rineka Cipta.

Azwar, S. (2014). Penyusunan Skala Psikologi. Yogyakarta: Pustaka Pelajar.

Baumeister, R. F., Bratslavsky, E., Muraven, M., \& Tice, D. M. (1998). Ego depletion: Is the active self a limited resource? Journal of Personality and Social Psychology, 74(5), 1252-1265.

Djarwanto, PS. dan Subagyo Pangestu. (1998). "Statistik Induktif", BPFE, Jakarta. Emilia

Ghozali, Imam. (2006). Aplikasi Analisis Multivariate Dengan Program SPSS. Cetakan Keempat. Semarang: Badan Penerbit Universitas Diponegoro

Ghufron, M.Nur; Risnawita, Rini. (2014). Teori-Teori Psikologi. Jakarta: Ar-Ruz Media.

Hurlock, E. B. (1994). Psikologi Perkembanga: Suatu Pendekatan Sepanjang Rentang Kehidupan. Jakarta : Erlangga

Karuniawan, A., \& Cahyanti, I. Y. (2013). Hubungan antara academic stress dengan Smartphone Addiction pada mahasiswa pengguna smartphone. 
Junal Psikologi Klinis dan Kesehatan Mental, 1(1), 16-21.

Kwon M, Kim DJ, Cho H, Yang S (2013)

Development and Validation of a

Smartphone Addiction Scale (SAS)

ONE journal 8(2): https://doi.org/10.1371/journal.pone.0 083558.https://www.researchgate.net/p ublication/235882951

Kwon M, Kim DJ, Cho H, Yang S (2013) The Smartphone Addiction Scale: Development and Validation of a Short Version for Adolescents. PLOS ONE journal $8(12)$ : e83558. https://doi.org/10.1371/journal.pone.0 083558

Lauren Leoti, Catherine, et.al. (2015). The Neural Basic Underlying the Experience of Control in the Human Brain, Part I Vilition, The Sense of Agency, Oxford University Press.

Monks. FJ dkk. (2006). Psikologi Perkembangan. Jakarta : Gadjah Mada University Press

Phythian, K., dkk. (2008). Family Structure and Parental Behavior: Identifying the Sources of Adolescent SelfControl:Western Criminology Review journal, 9, (2), hal 73-87.

Priyatno, Duwi. 2010. Paham Analisa Statistik Data dengan SPSS. Jakarta: MediaKom.

Sarafino, E. P. (1990). Health Psychology: Biopsychosocial Interactions. Oxford, England: John Wiley \& Sons.

Sugiyono. (2014). Metode Penelitian Pendidikan Pendekatan Kuantitatif, Kualitatif Dan R\&D. Bandung: Alfabeta.
Sujarweni, V. Wiratna. (2014). SPSS untuk Penelitian. Yogyakarta: Pustaka Baru Press.

Winarsunu. Tulus. (2010). Statistik dalam Penelitian psikologi \& Pendidikan. Malang: UMM Press. 